\title{
Fate of nitrogen atoms in the photocatalytic degradation of industrial (congo red) and alimentary (amaranth) azo dyes. Evidence for mineralization into gaseous dinitrogen
}

\author{
E. Puzenat, ${ }^{1}$ H. Lachheb, ${ }^{1,2}$ M. Karkmaz, ${ }^{1}$ A. Houas, ${ }^{2}$ \\ C. Guillard, ${ }^{1}$ and J. M. Herrmann ${ }^{1, \dagger}$ \\ ${ }^{1}$ Laboratoire de Photocatalyse, Catalyse et Environnement, (LPCE), UMR CNRS IFOS \\ no. 5621 Ecole Centrale Lyon 69134 Ecully Cedex, France \\ ${ }^{2}$ Laboratoire de Catalyse et Environnement; ENIG, Gabès, Tunisia
}

\begin{abstract}
The photocatalytic degradation of two azo-dyes-an industrial one (Congo Red (CR)), and an alimentary one (Amaranth (AM)) - has been investigated in $\mathrm{TiO}_{2} / \mathrm{UV}$ aqueous suspensions. In addition to a prompt removal of the colors, $\mathrm{TiO}_{2} / \mathrm{UV}$-based photocatalysis was simultaneously able to fully oxidize the dyes, with a complete mineralization of organic carbon into $\mathrm{CO}_{2}$. In particular, the aromatic rings were submitted to successive attacks by photogenerated $\mathrm{OH}^{\circ}$ radicals leading to hydroxylated metabolites before the ring opening and the final evolution of $\mathrm{CO}_{2}$ induced by repeated subsequent "photo-Kolbe" reactions with carboxylic intermediates. Simultaneously, sulfur heteroatoms were converted into innocuous $\mathrm{SO}_{4}{ }^{2-}$ ions. The mineralization of nitrogen was more complex to analyze. Nitrogen atoms in the -3 oxidation state, such as in the amino-groups of $\mathrm{CR}$, initially remained at this reduction degree and produced $\mathrm{NH}_{4}^{+}$cations, subsequently and very slowly converted into $\mathrm{NO}_{3}{ }^{-}$anions. For both azo-dyes (CR and AM) degradation, the overall mass balance in nitrogen was always found incomplete. Various experiments performed in pure oxygen in a vacuum-tight cell and then in an air-free photoreactor (but filled with pure oxygen) enabled us to put in evidence the formation of $\mathrm{N}_{2}$. Quantitative measurements clearly indicated that gaseous dinitrogen evolved stoichiometrically corresponded to the mineralization of the central $-\mathrm{N}=\mathrm{N}-$ azo-group. This constitutes the ideal issue for the elimination of nitrogen-containing pollutants, not only for environmental photocatalysis but also for any other physicochemical method. These results suggest that $\mathrm{TiO}_{2} / \mathrm{UV}$ photocatalysis may be envisaged as a method for treatment of diluted colored waste waters not only for decolorization but also for total detoxification, in particular in textile industries in semi-arid countries.
\end{abstract}

\section{INTRODUCTION}

Waste waters generated by the textile industries are known to contain considerable amounts of non fixed dyes and especially of azo-dyes. It is well known that some azo-dyes and degradation products such as aromatic amines are highly carcinogenic [1]. 15\% of the total world production of dyes is lost during the dyeing process and is released in textile effluents [2]. The release of those colored waste waters in the ecosystem is a dramatic source of esthetic pollution, of eutrophication and of perturbations in the aquatic life. As international environmental standards are becoming more stringent (ISO 14001, October 1996), technological systems for the removal of organic pollutants, such as dyes have been recently developed. Among them, physical methods, such as adsorption [3], biological methods (biodegradation) $[4,5]$ and chemical methods (chlorination, ozonation [6]) are the most frequently used. The traditional processes for treatment of these effluents prove to be insufficient to purify the important quantity

\footnotetext{
${ }^{\dagger}$ E-mail: jean-marie.herrmann@ec-lyon.fr
}

of waste waters after the different operations of textile dyeing and washing. Some methods such as combined coagulation, electrochemical oxidation, active sludge have recently been investigated and proved to be adequate [7] Other methods such as flocculation, reverse osmosis and adsorption on activated carbon have also been tested [8-10]. The drawbacks of these methods are mainly the creation of a more concentrated pollutant-containing phase. The processes by bacterial beds are less adapted because of the fluctuations of the wastewater composition [11, 12].

However, the recent developments of chemical treatment of waste waters gave birth to an improvement of the oxidative degradation of the organic compounds dissolved or dispersed in aqueous media. Among the new oxidation methods called "Advanced Oxidation Processes" (AOP), heterogeneous photocatalysis has appeared as an emerging destructive technology leading to the total mineralization of most of organic pollutants [13-19]. A quasi-exhaustive list of various families of organic pollutants which can be treated by photocatalysis has been given in ref. [20]. In most cases, the degradation is conducted for dissolved 


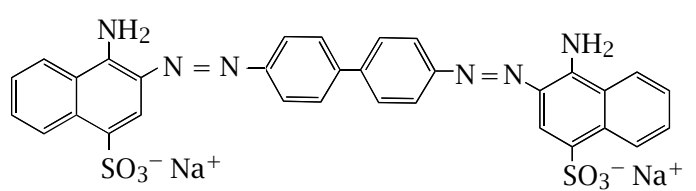

CONGO RED (Industrial Dye)

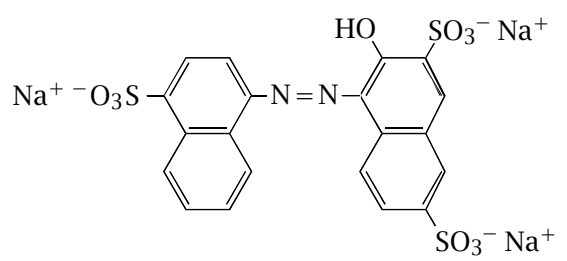

AMARANTH (Prohibited alimentary Dye (EPA))

Figure 1. Developed formulae of Congo Red (CR) and Amaranth (AM).

compounds in water with UV-illuminated titania. The great present interest is to use solar light which is free and inexhaustible.

In the present article, it was attempted to determine the feasibility of the total degradation by a $\mathrm{UV} / \mathrm{TiO}_{2}$ treatment of two azo-dyes, the first one being an industrial coloring agent, Congo Red (CR), known as a very recalcitrant dye to be eliminated in printing and in paper industry [21] and the other one being a recently prohibited alimentary colorant, amaranth (AM). Their developed formulae are given in Figure 1. The photocatalytic degradation pathway with the identification of the main degradation metabolites has already been established in our laboratories for three other dyes (methylene blue [22], indigo and indigo carmine [23]).

The second main objective was to establish the nitrogen balance since it has been established that some nitrogen was missing in the preliminary analytical quantifications in the aqueous phase. Nitrogen has already been a complex element in chemistry because of its apparent inertness as $\mathrm{N}_{2}$ and of its multiple oxidation states, ranging from -3 to +5 . The photocatalytic degradation of $\mathrm{N}$-containing pollutants has always been difficult in following the fate of nitrogen atoms in the final products [24, 25]. Nitro-compounds were found to decompose into nitrite, easily oxidized into nitrate. Amino groups have been found to decompose into ammonium ions, slowly oxidizable later into nitrate. Eventually, nitrogen atoms incorporated into triazinic aromatic rings were found to resist oxidation, remaining in their -3 oxidation state. This was exemplified by the partial oxo-degradation of s-triazine into cyanuric acid $\mathrm{C}_{3} \mathrm{H}_{3} \mathrm{O}_{3} \mathrm{~N}_{3}$ (25). Fortunately, cyanuric acid is innocuous because of its very high stability. It constitutes one of the three very few examples of organics resisting photocatalytic degradation at room temperature with trifluoro-acetic acid and CFC's. This is due (i) to the three bonds of $\mathrm{N}$ atoms involved in the aromatic ring skeleton (i.e. without aliphatic substituents) and (ii) to the maximum formal oxidation state of carbon $(+4)$, already reached in $\mathrm{C}_{3} \mathrm{H}_{3} \mathrm{O}_{3} \mathrm{~N}_{3}$.

Nitrogen atoms in the -3 oxidation state, such as in the amino-groups of $\mathrm{CR}$, generally remained at this reduction degree and produced $\mathrm{NH}_{4}{ }^{+}$cations, subsequently and very slowly converted into $\mathrm{NO}_{3}{ }^{-}$ions. Since the total number of $\mathrm{N}$ atoms present as ammonium and nitrate did not equal that of initial ones, this prompted us to follow the gas phase composition.

\section{EXPERIMENTAL}

2.1. Materials. Degussa P-25 titanium dioxide was used as the photocatalyst. It is mostly in the anatase form and has a B.E.T. surface area of $50 \mathrm{~m}^{2} / \mathrm{g}$ corresponding to a mean particle size of ca. $30 \mathrm{~nm}$. Both dyes were purchased from Fluka and used as received without further purification. Their solutions were prepared using water from a Millipore Waters Milli Q purification unit.

2.2. Apparatus. Two types of Pyrex reactors opened to air were utilised. Reactor 1 (90 mL) described in Figure 2, is particular well adapted to perform simultaneously both gas and liquid phase sampling as a function of time to establish kinetics isotherms. It has a bottom optical window of ca. $11 \mathrm{~cm}^{2}$, through which the suspension was irradiated. Constant agitation of the solution was insured by a magnetic stirrer placed at right angle from the reactor basis. UVirradiation was provided by a high pressure mercury lamp (Philips HPK-125W). The IR beams were removed by making the irradiation pass through a $2.2 \mathrm{~cm}$ thick circulating-water cuvette equipped with either Pyrex filter transmitting wavelengths $>290 \mathrm{~nm}$ or a Corning Glass 0.52 cut-off filter, transmitting wavelengths $>340 \mathrm{~nm}$. The photon flux of the UV-radiation reaching the reactor was measured to be $6.94 \times 10^{-7} \mathrm{~mol}$ of photons/s for the Pyrex filter and $2.39 \times 10^{-7} \mathrm{~mol}$ of photons/s for the 0.52 Corning filter. Reactor 2 (1 L) was used to make samplings of greater aliquots for dye analyses with a spectrophotometer. It was equipped with a plunging tube in which a Philips HPK $125 \mathrm{~W}$ lamp, identical to that used in Reactor 1, was placed vertically. To avoid the heating of the solution, water was circulated through a cylindrical jacket, made of Pyrex and located around the plunging tube. The photon flux of the UV radiation reaching the exposed inner part of the reactor at $\lambda>290 \mathrm{~nm}$ was measured to be around $6 \times 10^{-6}$ mols of photons per second.

2.3. Procedure. The volume of the aqueous solution of each dye introduced into Reactor 1 was $20 \mathrm{~mL}$, to which $50 \mathrm{mg}$ of powder $\mathrm{TiO}_{2}$ was added $\left(2.5 \mathrm{~g} \mathrm{~L}^{-1}\right)$. 


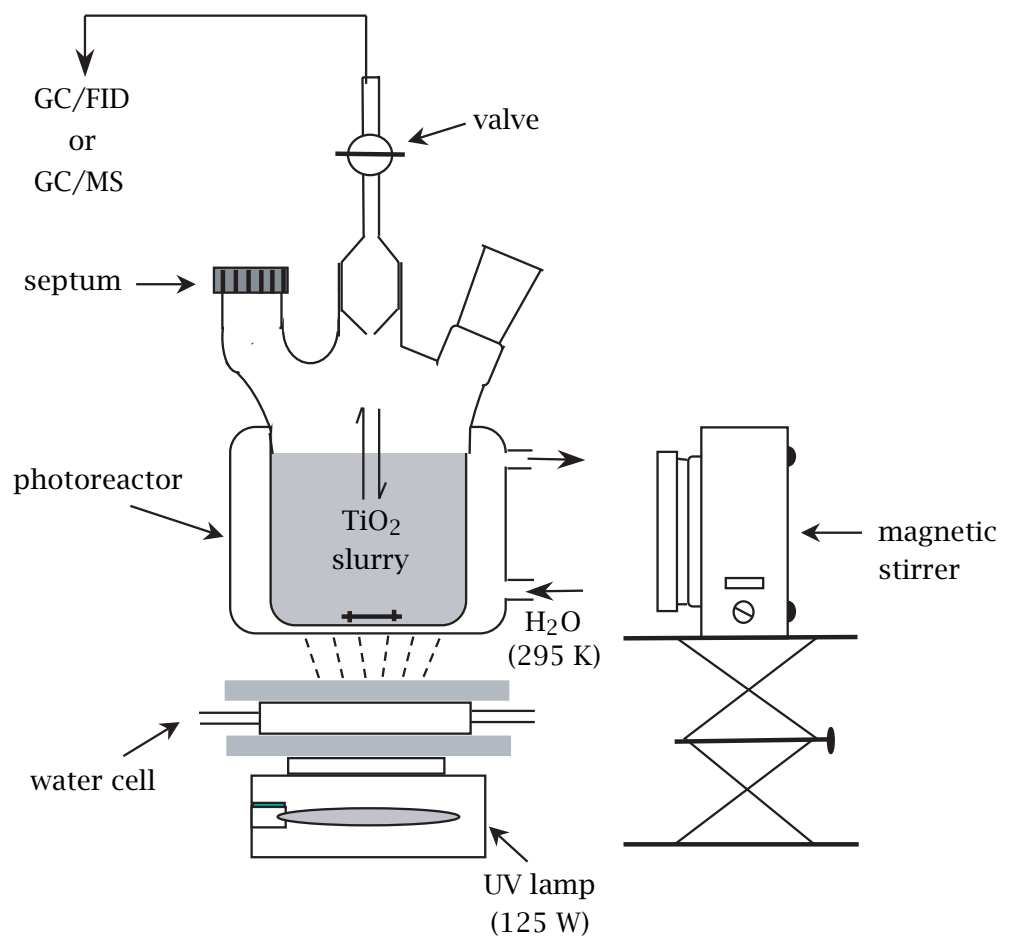

Figure 2. Scheme of static batch Photocreator 1.

In Reactor 2, the suspension contained $750 \mathrm{ml}$ of solution and $375 \mathrm{mg}$ of $\mathrm{TiO}_{2}\left(0.5 \mathrm{~g} \mathrm{~L}^{-1}\right)$. In both cases, the amount of titania has been adjusted for a full absorption of the incident photon flux.

The degradations were carried out at $293 \mathrm{~K}$ and at different $\mathrm{pH}$ 's. The $\mathrm{pH}$ was adjusted using either $\mathrm{NaOH}$ or $\mathrm{HNO}_{3}$. The suspension was first stirred in the dark for $60 \mathrm{~min}$ before irradiation to reach equilibrated adsorption as deduced from the steady-state concentrations. To determine the adsorption constants, different concentrations of dyes were used.

2.4. Analyses. Before analysis, the aqueous samples were filtered through $0.45 \mu \mathrm{m}$ millipore discs to remove $\mathrm{TiO}_{2}$ agglomerates. The UV/vis spectrophotometer used for the determination of dye disappearance kinetics was a "Safas Monaco 2000" UV/Vis spectrometer recording the spectra over the $190-750 \mathrm{~nm}$. Calibration plots based on Beer-Lambert's law were established relating the absorbance to the concentration. Each plot was determined at the maximum of absorbance of each dye ( $510 \mathrm{~nm}$ for CR and $522 \mathrm{~nm}$ for AM).

Anions and cations were analysed by HPLC using a Waters 501 isocratic pump, a Waters 431 conductivity detector, and an IC-PAK HR anion column $(\mathrm{L}=50 \mathrm{~mm}$, Øi.d. $=4.6 \mathrm{~mm}$, Øparticules $=10 \mu \mathrm{m}$ ) or a Vydac Cation IC40 $(\mathrm{L}=50 \mathrm{~mm}$, Øi.d. $=4.6 \mathrm{~mm})$. Eluents were respectively borate/gluconate at $0.9 \mathrm{ml} / \mathrm{min}$ and $\mathrm{HNO}_{3} 2.5 \mathrm{mM}$ at $1.5 \mathrm{~mL} / \mathrm{min}$.
Total Organic Carbon (TOC) was determined by using a Bioritech (model 700) TOC analyzer. Chemical Oxygen Demand (COD) was made using acidic dichromate method with a Bioblock COD analyzer.

\section{RESULTS AND DISCUSSION}

3.1. Adsorption of both dyes on titania. The kinetics of adsorption of both dyes indicated that the steady state of adsorption was reached within $1 \mathrm{~h}$ for $\mathrm{CR}$, whereas no detectable adsorption could be observed for AM. Therefore, a duration of $1 \mathrm{~h}$ has been selected for the initial period in the dark previously to UV-irradiation at time $t_{U V}=0$ to make sure that the initial degradation initiates at the equilibrium of adsorption. For CR, the linearity of the transform of the Langmuirian plot $1 / \mathrm{n}_{(\mathrm{ads})}=\mathrm{f}\left(1 / \mathrm{C}_{\mathrm{e}}\right)$ clearly indicated that the Langmuir isotherm was correctly observed, implying a monolayer adsorption model. From these data, one could determine for CR the maximum quantitiy $q_{\max }$ of adsorbed dye $\left(18.2 \mu \mathrm{mol} / \mathrm{g}_{\text {cat }}\right)$, the adsorption constants $K_{\text {ads }}\left(2 \times 10^{3} \mathrm{~L} / \mathrm{mol}\right)$ and the areal density of adsorbed CR $\left(0.22\right.$ molecule $\left./ \mathrm{m}^{2}\right)$, the adjective "areal" referring to a surface area unit, as defined by Burwell in the IUPAC report in ref. [26].

3.2. Photocatalytic degradation of the dyes. After checking that no detectable degradation occurred in the absence of titania or of UV-irradiation, the 

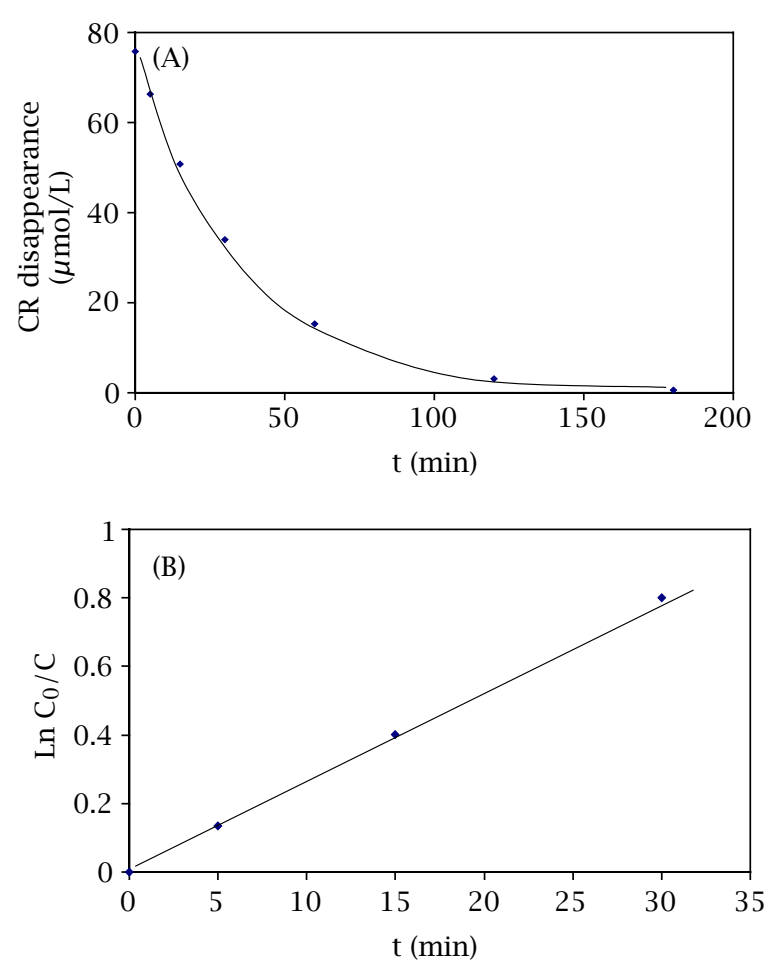

Figure 3. (A) Kinetics of CR dye disappearance. (B): Apparent first order linear transform $\mathrm{Ln}=\left(\mathrm{C}_{0} / \mathrm{C}\right)=\mathrm{f}(\mathrm{t})$.

photocatalytic disappearance of the dyes was performed according to the procedure indicated in the Experimental section. The kinetics are given in Figures 3(A) and 4(A). All reactions followed an apparent first order rate law, verified by the linear transforms $\mathrm{ln}$ $\mathrm{C}_{0} / \mathrm{C}=\mathrm{f}(\mathrm{t})$ illustrated by Figures 3(B) and 4(B).

Influence of pH. Since dyes to be degraded can be at different pH's in colored effluents, comparative experiments were performed at three $\mathrm{pH}$ values: 3, 6 and 9. $\mathrm{pH}$ had a little influence upon the kinetics of disappearance. The results, represented under the form of linear transforms $\log \left(\mathrm{k}_{\mathrm{app}}\right)=\mathrm{f}\left(\log \left[\mathrm{H}^{+}\right]\right)=\mathrm{f}(-\mathrm{pH})$ enabled one to determine the kinetic partial order $n$ with respect to proton concentration by measuring the slopes of the curves. The value being close to zero ( $\mathrm{n}=-0.1$ ), this clearly indicates that protons do not intervene in the rate limiting step of the photocatalytic system, in agreement with other results on pollutant removal. However, although the partial kinetic order $n$ with respect to $\left[\mathrm{H}^{+}\right]$is very small, its negative sign is significant and informative.

The $\mathrm{pH}$ influences at the same time both the surface state of titania and the ionization state of ionizable organic molecules. For pH's higher than the pzc of titania, the surface becomes negatively charged and it is the opposite for $\mathrm{pH}$ 's < pzc, according to the following equilibria:

$$
\mathrm{pH}<\mathrm{pzc}: \quad \mathrm{Ti}-\mathrm{OH}+\mathrm{H}^{+} \Longleftrightarrow \mathrm{TiOH}_{2}{ }^{+},
$$
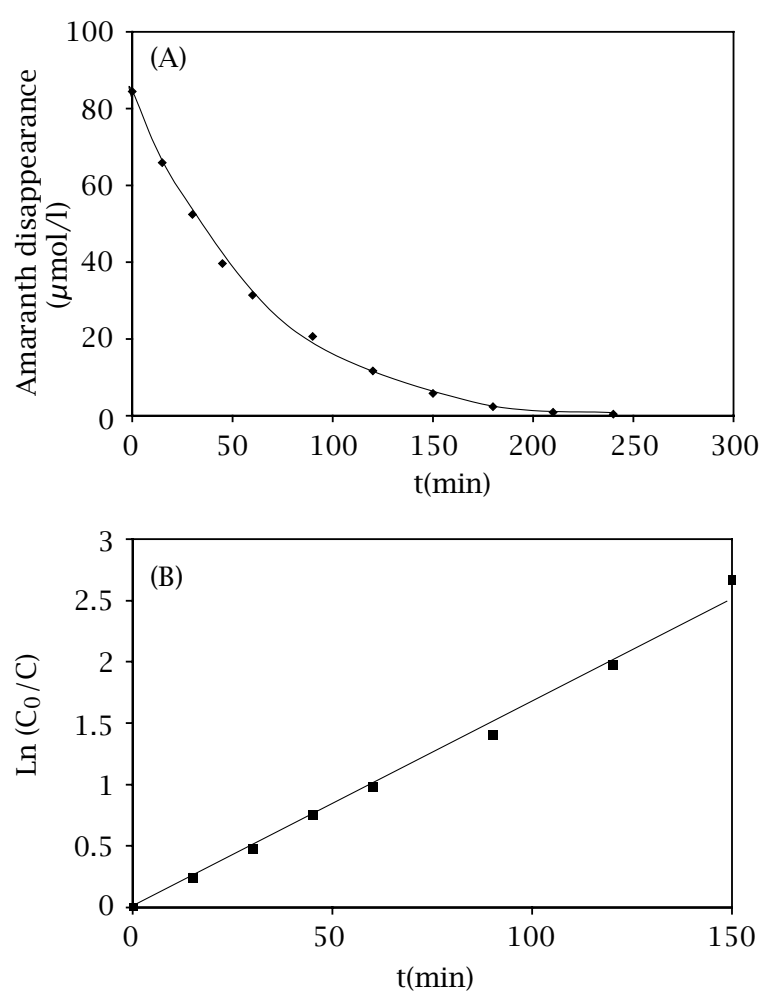

Figure 4. (A): Kinetics of AM dye disappearance. (B): Appearent first order linear transform $\operatorname{Ln}\left(\mathrm{C}_{0} / \mathrm{C}\right)=\mathrm{f}(\mathrm{t})$.

$$
\mathrm{pH}>\mathrm{pzc}: \mathrm{Ti}-\mathrm{OH}+\mathrm{OH}^{-} \Longleftrightarrow \mathrm{TiO}^{-}+\mathrm{H}_{2} \mathrm{O} .
$$

When $\mathrm{pH}$ increases, the surface of titania becomes negatively charged and tends to repel the anionic sulfonate groups of both dyes. This explains the negative (even limited) effect of $\mathrm{pH}$ both on adsorption and on the sign of the kinetic order with respect to $\left[\mathrm{H}^{+}\right]$.

\subsection{Kinetics of the total mineralization of the} dyes. The kinetics of the total mineralization of the dyes has been followed using two overall techniques, the disappearance of the Chemical Oxygen Demand (COD) and that of the Total Organic Carbon (TOC), both techniques being complementary for expressing the detoxification level of water.

\subsubsection{Kinetics of COD disappearance}

The kinetics isotherms of COD disappearance are given in Figure 5. COD has totally disappeared in less than 4 and 6 hours for CR and AM, respectively. The initial values plotted in the $y$-axis are in agreement with the chemical formulae given in Figure 1 and with the stoichiometric coefficients expressed in the expected overall reactions:

$$
\begin{aligned}
& \mathrm{C}_{32} \mathrm{H}_{22} \mathrm{~N}_{6} \mathrm{O}_{6} \mathrm{~S}_{2}{ }^{2-}+91 / 2 \mathrm{O}_{2} \\
& \longrightarrow 32 \mathrm{CO}_{2}+6 \mathrm{NO}_{3}{ }^{-}+2 \mathrm{SO}_{4}{ }^{2-}+8 \mathrm{H}^{+}+7 \mathrm{H}_{2} \mathrm{O}
\end{aligned}
$$



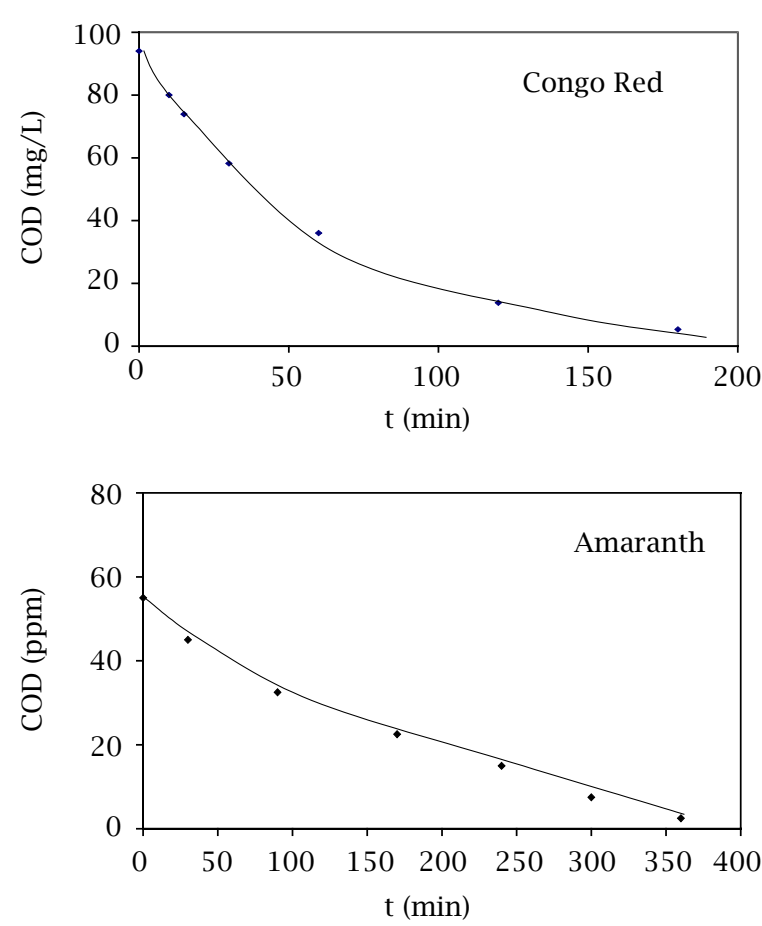

Figure 5. Kinetics of COD dye disappearance.

$$
\begin{aligned}
\mathrm{C}_{20} \mathrm{H}_{11} \mathrm{~N}_{2} \mathrm{O}_{10} \mathrm{~S}_{3}{ }^{3-}+51 / 2 \mathrm{O}_{2} \\
\longrightarrow 20 \mathrm{CO}_{2}+2 \mathrm{NO}_{3}{ }^{-}+3 \mathrm{SO}_{4}{ }^{2-}+5 \mathrm{H}^{+}+3 \mathrm{H}_{2} \mathrm{O}
\end{aligned}
$$

\subsubsection{Kinetics of TOC disappearance}

The kinetics isotherms of TOC disappearance [TOC] $=$ $\mathrm{f}(\mathrm{t})$ are given in Figure 6. TOC has totally disappeared in less than 7 hours for CR and AM. Both initial and temporal TOC values are in agreement with the stoichiometries of the molecule degradations expressed above. It is generally admitted that both aliphatics and aromatic rings are submitted to successive attacks by photogenerated $\mathrm{OH}^{\circ}$ radicals, known as the strongest oxidizing species (after fluorine). This leads to various hydroxylated metabolites before the ring opening. The final evolution of $\mathrm{CO}_{2}$ is induced by repeated subsequent "photo-Kolbe" reactions with carboxylic intermediates resulting from the neutralization of the carboxylic group by a hole:

$$
\begin{gathered}
\left(\mathrm{TiO}_{2}\right)+h v \rightarrow \mathrm{e}^{-}+\mathrm{p}^{+} \\
\mathrm{R}-\mathrm{COO}^{-}+\mathrm{p}^{+} \longrightarrow \mathrm{R}^{\circ}+\mathrm{CO}_{2}
\end{gathered}
$$

Such easy reactions initially proposed by Bard [27], have already been observed for polycarboxylic [28] and chloro-benzoic [29] acids.

Both parameters (COD and TOC), which directly evaluate the pollution level of an aqueous solution, do not exhibit similar disappearance patterns (compare Figures 5 and 6). This could be accounted for by the influence of the different molecular structures of
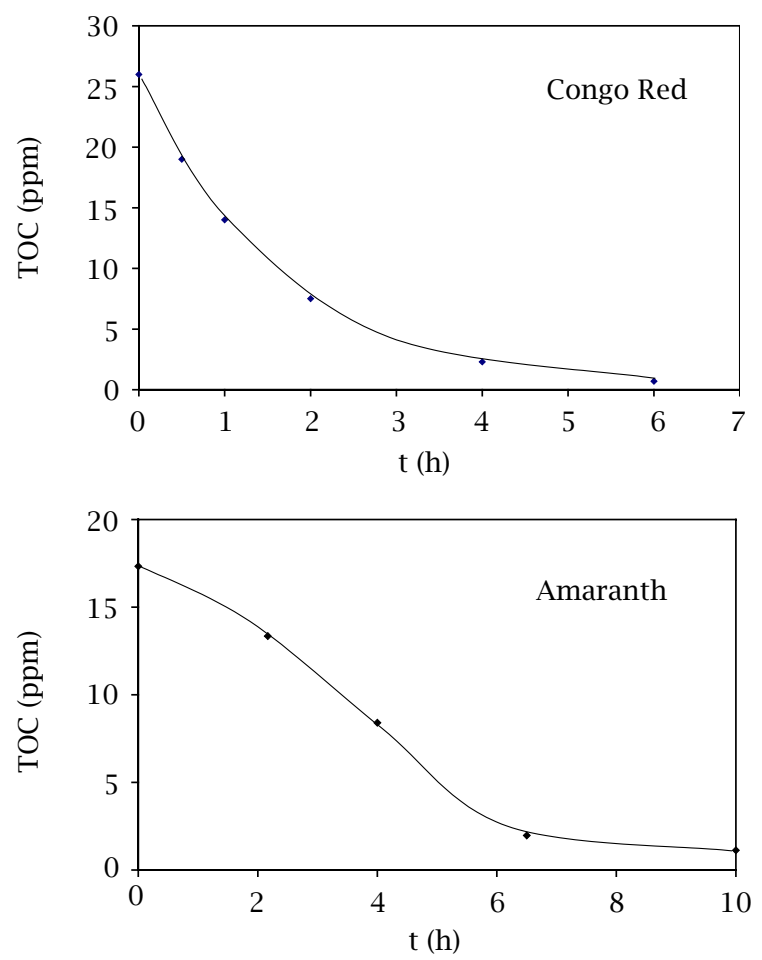

Figure 6. Kinetics of TOC dye disappearance.

the dyes on their reactivities with $\mathrm{OH}^{\circ}$ radicals which constitute the main oxidizing agents generated in UVirradiated aqueous suspensions of titania, and which are produced as follows:

$$
\begin{aligned}
& \mathrm{H}_{2} \mathrm{O}+\left(\mathrm{TiO}_{2}\right) \longrightarrow \mathrm{OH}^{-}{ }_{(\text {ads })}+\mathrm{H}^{+}{ }_{(\text {ads })} \\
& \mathrm{OH}^{-}{ }_{(\mathrm{ads})}+\mathrm{p}^{+} \longrightarrow \mathrm{OH}^{\circ}{ }_{(\mathrm{ads})} .
\end{aligned}
$$

From the toxicological point of view, TOC analysis seems more accurate and appropriate for evaluating the decontamination of polluted waters containing organics since it takes into account all the residual carbon-containing metabolites.

\subsubsection{Kinetics of $\left[\mathrm{H}^{+}\right]$variations during the mineralization reaction}

In a UV-irradiated titania slurry, $\mathrm{pH}$ is a rather complex parameter since it concerns (i) the water dissociation equilibrium, (ii) the surface charge of titania with respect to its pzc (eqs. (1) and (2)) and (iii) the ionization state of the organic reactants and of their metabolites. However, its temporal variations were in agreement with the stoichiometry of both overall oxidation reactions listed above with $\left[\mathrm{H}^{+}\right]=10^{-\mathrm{pH}}$ equilibrating the negative electrical charges of anions.

\subsubsection{Kinetics of inorganic ions evolution during the mineralization reaction}

Besides TOC elimination and $\mathrm{H}^{+}$and $\mathrm{CO}_{2}$ evolution, mineralization implies the appearance of inorganic 

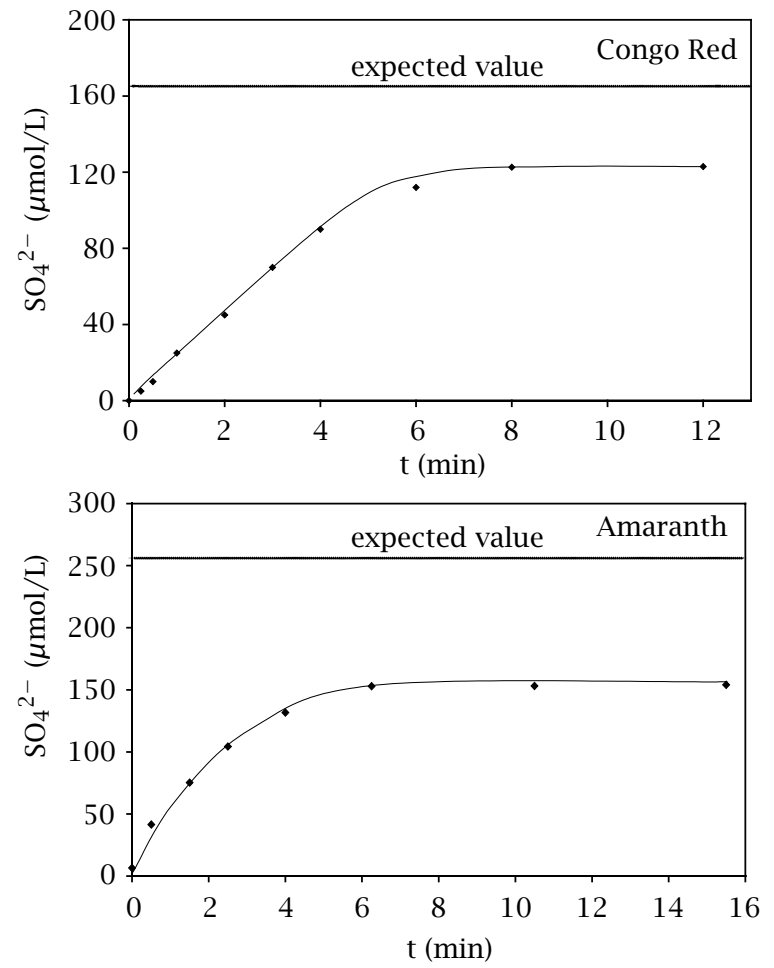

Figure 7. Kinetics of sulfate ions appearance.

products, mainly anions, since hetero-atoms are generally converted into anions in which they generally are at their highest oxidation degree $[13,16]$.

Evolution of sulfate ions. The temporal evolution of $\mathrm{SO}_{4}{ }^{2-}$ ions is presented in Figure 7. Actually, the release of $\mathrm{SO}_{4}{ }^{2-}$ from sulfonate groups does not correspond to an oxidation of sulfur since sulfur is already in its +6 expected final state. In both cases, the initial slopes $\mathrm{d}\left[\mathrm{SO}_{4}{ }^{2-}\right] / \mathrm{dt}$ are positive, indicating that $\mathrm{SO}_{4}{ }^{2-}$ ions are initial products, directly resulting from the initial attack on the sulfonyl groups. The release of $\mathrm{SO}_{4}{ }^{2-}$ can be accounted for by an initial attack by a photoinduced $\mathrm{OH}^{\circ}$ radical:

$$
\begin{aligned}
& \mathrm{OH}^{-}+\mathrm{p}^{+} \longrightarrow \mathrm{OH}^{\circ}, \\
& \mathrm{R}-\mathrm{SO}_{3}{ }^{-}+\mathrm{OH}^{\circ} \longrightarrow \mathrm{R}^{\circ}+\mathrm{HSO}_{4}{ }^{-}, \\
& \mathrm{HSO}_{4}{ }^{-} \longrightarrow \mathrm{SO}_{4}{ }^{2-}+\mathrm{H}^{+} \text {. }
\end{aligned}
$$

The attack of sulfonate groups would be favored if the molecule is adsorbed with its $\mathrm{SO}_{3}{ }^{-}$group orientated to the surface. Surprisingly, the sulfur-containing dyes did not release the expected stoichiometric quantities of sulfate. It has already been observed that sulfate ions can remain partially adsorbed at the surface of titania $[16,23]$.

Evolution of nitrogen-containing final products. The kinetics of $\mathrm{NO}_{3}{ }^{-}$and $\mathrm{NH}_{4}{ }^{+}$release in water are given in Figure 8. According to literature, the formation

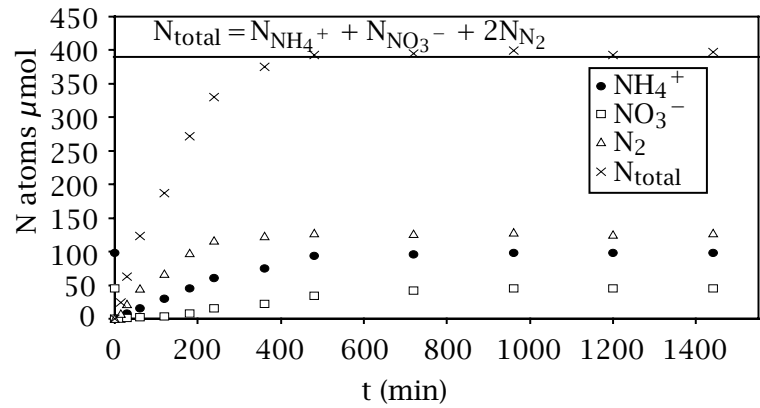

Figure 8. Kinetics of appearance of nitrogen-containing intermediates. Temporal nitrogen balance during CR photocatalytic degradation.

of these ions $\left(\mathrm{NH}_{4}{ }^{+}\right.$and $\left.\mathrm{NO}_{3}{ }^{-}\right)$is not unexpected. $\mathrm{NH}_{4}{ }^{+}$ ions can originate from the two amino-groups of $\mathrm{CR}$ without any change of the oxidation degree of nitrogen equal to -3 . This can occur via successive attacks by $\mathrm{H}^{\circ}$ atoms:

$$
\begin{gathered}
\mathrm{R}-\mathrm{NH}_{2}+\mathrm{H}^{\circ} \longrightarrow \mathrm{R}^{\circ}+\mathrm{NH}_{3}, \\
\mathrm{NH}_{3}+\mathrm{H}^{+} \longrightarrow \mathrm{NH}_{4}^{+} .
\end{gathered}
$$

$\mathrm{H}^{\circ}$ atoms can be generated by redox reactions such as the photo-Kolbe reaction [27] of formate metabolite:

$$
\mathrm{H}-\mathrm{COO}^{-}+\mathrm{h}^{+} \longrightarrow \mathrm{H}^{\circ}+\mathrm{CO}_{2} .
$$

By comparing the initial rates, $\mathrm{NH}_{4}{ }^{+}$appears as a primary product by contrast to $\mathrm{NO}_{3}{ }^{-}[22,23,30]$ in line with eqs. (12) and (13).

However, no nitrogen balance could be established in solution for both dyes. This prompted us to perform wider and deeper analyses, including all reactants and products simultaneously present, especially those in the gas phase.

The first semiquantitative experiments were performed in a vacuum-tight static cell connected to a mass-spectrometer. A small amount $(20 \mathrm{mg}$ ) of Degussa P-25 was first impregnated with a Congo Red solution, then dried in air at ambient temperature to make sure that the hydration and hydroxylation degrees were high enough for enabling photocatalytic degradation, before being introduced in the reaction cell. This static cell was evacuated at $10^{-5}$ Torr $\left(1.33 \times 10^{-3} \mathrm{~Pa}\right)$ overnight to get an atmosphere compatible with mass spectrometry analyses. It was subsequently filled with pure oxygen (L'Air Liquide; $99.9995 \%$ purity) under the maximum pressure of 1 Torr $(133.3 \mathrm{~Pa})$, still compatible with the working conditions of the MS. It was checked that there remained all chemisorbed water on titania, which is indispensable for degradation oxidation, as a source of photo-induced $\mathrm{OH}^{\circ}$ radicals (3). At time $\mathrm{t}_{\mathrm{UV}}=0$, four peaks appeared at $\mathrm{m} / \mathrm{z}=12$, 14, 28 and 44 and increased. The interpretation of 
the mass-spectra confirmed the total mineralization of carbon atoms as $\mathrm{CO}_{2}(\mathrm{~m} / \mathrm{z}=44)$. The peak at $\mathrm{m} / \mathrm{z}=$ 28 can generally be attributed to $\mathrm{CO}, \mathrm{N}_{2}$ and $\mathrm{C}_{2} \mathrm{H}_{4}$. Since there is no peak at $\mathrm{m} / \mathrm{z}=27$, the formation of $\mathrm{C}_{2} \mathrm{H}_{4}$ can be ruled out. The presence of $\mathrm{CO}$ in the peak at $\mathrm{m} / \mathrm{z}=28$ was confirmed by the increase of the peak at $\mathrm{m} / \mathrm{z}=12$. The presence of $\mathrm{CO}$ did not arise from the dye but from the fragmentation of $\mathrm{CO}_{2}$ in the mass spectrometer. The other contribution to the peak at $\mathrm{m} / \mathrm{z}=28$ has to be attributed to $\mathrm{N}_{2}$ whose presence is confirmed by the fragment peak $\mathrm{N}$ at $\mathrm{m} / \mathrm{z}=14$.

After this clear evidence by MS of nitrogen formation, a second series of quantitative experiments were performed on both dyes in an air-tight batch slurry photoreactor, whose head space and ambient air was previously flushed out with pure oxygen until removing nitrogen. It was then connected to an air-tight GC loop, linked to an air-tight 6-way valve of a gas chromatograph enabling the on-line quantification of $\mathrm{N}_{2}$ evolved. In our conditions, $\mathrm{N}_{2}$ evolution from Congo Red reached a plateau at $\mathrm{t}_{\mathrm{UV}}=400 \mathrm{~min}$ (Figure 8 ). The mass balance in nitrogen was equal to $100 \%$. In addition, the ratio $2 \mathrm{n}_{\mathrm{N}_{2}} /\left[\left(\mathrm{n}_{\mathrm{NH}_{4}}{ }^{+}+\mathrm{n}_{\mathrm{NO}_{3}{ }^{-}}\right)+2 \mathrm{n}_{\mathrm{N}_{2}}\right]$ was found equal to 0.65 , just corresponding to the ratio $2 / 3$ of the number of $\mathrm{N}$ atoms contained in the double $-\mathrm{N}=\mathrm{N}-$ azo-groups of Congo-Red. Similar results were found with the single azo-group dye in Amaranth. This means that photocatalytic degradation is able to generate gaseous di-nitrogen. This seems possible for two reasons: (i) the azo-group $-\mathrm{N}=\mathrm{N}-$, as a potential precursor of $\mathrm{N} \equiv \mathrm{N}$, has already one double bond existing; (ii) nitrogen atoms in $-\mathrm{N}=\mathrm{N}-$, are formally already at the zero oxidation state, i.e. that of nitrogen in $\mathrm{N}_{2}$ (zero by convention). The formation of $\mathrm{N}_{2}$ from diazoic dyes can be accounted for by a simple reaction with a radical, referring indifferently to an oxidation or of a reduction process such as:

$$
\mathrm{R}-\mathrm{N}=\mathrm{N}-\mathrm{R}^{\prime}+\mathrm{OH}^{\circ} \longrightarrow \mathrm{R}-\mathrm{N}=\mathrm{N}^{\circ}+\mathrm{R}^{\prime}-\mathrm{OH}
$$

or

$$
\mathrm{R}-\mathrm{N}=\mathrm{N}-\mathrm{R}^{\prime}+\mathrm{R}^{\prime \prime \circ} \longrightarrow \mathrm{R}-\mathrm{N}=\mathrm{N}^{\circ}+\mathrm{R}^{\prime}-\mathrm{R}^{\prime \prime} .
$$

Then

$$
\mathrm{R}-\mathrm{N}=\mathrm{N}^{\circ} \longrightarrow \mathrm{R}^{\circ}+\mathrm{N} \equiv \mathrm{N} .
$$

Radicals $\mathrm{R}^{\circ}$ subsequently follow the same degradation process by additional $\mathrm{OH}^{\circ}$ radicals. It appears that the fate of nitrogen strongly depends on its initial oxidation degree. When present in the -3 state as in amino groups, nitrogen spontaneously evolves as $\mathrm{NH}_{4}{ }^{+}$ cations with the same oxidation degree, before being subsequently and slowly oxidized into nitrate. In azodyes, the formal oxidation degree of nitrogen, equal to zero and combined with the existence of a $-\mathrm{N}=\mathrm{N}-$ double bond in the initial pollutant molecule, favors the evolution of gaseous dinitrogen. $\mathrm{N}_{2}$ evolution constitutes the ideal case for a decontamination reaction involving totally innocuous nitrogen-containing final product.

\section{CONCLUSION}

It has been demonstrated that single or poly-azo dyes could be not only decolorized but also totally mineralized into $\mathrm{SO}_{4}{ }^{2-}, \mathrm{NH}_{4}{ }^{+}$and $\mathrm{NO}_{3}{ }^{-}$ions in solution and into $\mathrm{CO}_{2}$ and $\mathrm{N}_{2}$ in the gas phase. Gaseous dinitrogen evolved quantitalively from both $-\mathrm{N}=\mathrm{N}-$ azogroups present in the molecule of $\mathrm{CR}$, known as a very recalcitrant dye to be eliminated in printing and in paper industry [21]. To our knowledge, this is the first example of nitrogen evolution in the aqueous photocatalytic degradation of N-containing pollutants. In addition, this constitutes an ideal example of water decontamination with the elimination of $\mathrm{N}$-atoms as dinitrogen from large and complex undesirable polluting molecules.

These results suggest that $\mathrm{TiO}_{2} / \mathrm{UV}$ photocatalysis may be envisaged as a method for treatment of diluted colored waste waters not only for decolorization but also for detoxification, in particular in textile industries in semi-arid countries.

\section{ACKNOWLEDGEMENTS}

This work was partly supported by the France-Tunisia Cooperation CMCU program (Project \# 99F1201), the French Ministry of Foreign Affairs, the Syrian Ministry of Education and French CNRS.

\section{REFERENCES}

[1] M. A. Brown and S. C. De Vito, Critical Reviews in Environmental Science and Technology 23 (1993), 249.

[2] H. Zollinger, Color Chemistry. Synthesis, Properties and Applications of Organic Dyes and Pigments, $2^{\text {nd }}$ revised Edition, VCH, 1991.

[3] P. B. Dejohn and R. A. Hutchins, Tex. Chem. Color. 8 (1976), 69

[4] S. S. Patil and V. M. Shinde, Environ. Sci. Technol. 22 (1988), 1160.

[5] A. T. More, A. Vira, and S. Fogel, Environ. Sci. Technol. 23 (1989), 403.

[6] A. Y. Slokar and A. M. Le Marechal, Dyes and Pigments 37 (1998), 335.

[7] S. H. Lin and C. F. Peng, Wat. Res. 30 (1996), 587.

[8] P. J. Halliday and S. Beszedits, Can. Textile J. 103 (1986), 78.

[9] G. S. Gupta, G. Prasad, and V. N. Singh, Water Research 24 (1990), 45.

[10] K. R. Ramakrishn and T. Viraraghavan, Wat. Sci. Tech. 36 (1997), 189. 
[11] R. H. Horning, Textile Chemist and Colorist. 9 (1997), 24.

[12] U. Pagga and D. Brown, Chemosphere 15 (1986), 479.

[13] J. M. Herrmann, Chapter 9: Water Treatment by Heterogeneous Photocatalysis in Environmental Catalysis, (F. Jansen and R. A. van Santen, Eds.), vol. 1, Imperial College Press, London, Catalytic Science Series, 1999, pp. 171-194

[14] M. Schiavello (Ed.), Photocatalysis and Environment. Trends and applications, Kluwer Acad. Pub. Dordrecht, 1988.

[15] N. Serpone and E. Pelizzetti (Eds.), Photocatalysis. Fundamentals and Applications, Wiley Interscience, New York, 1989.

[16] J. M. Herrmann, C. Guillard, and P. Pichat, Catalysis Today 17 (1993), 7.

[17] H. A. Al-Ekabi and D. Ollis (Eds.), Photocatalytic Purification and Treatment of Water and Air, Elsevier Science Pub. B. V., Amsterdam, 1993.

[18] D. W. Bahnemann, J. Cunningham, M. A. Fox, E. Pelizzetti, P. Pichat, and N. Serpone, Aquatic Surface Photochemistry (R. G. Zeep, G. R. Helz, D. G. Crosby, and F. L. Lewis, Publishers), Boca Raton, 1994, p. 261.

[19] O. Legrini, E. Oliveros, and A. M. Braun, Chem. Rev. 93 (1993), 671.
[20] D. M. Blake, Bibliography of work on the Photocatalytic removal of hazardous compounds from water and air. NREL/TP-430-22197, National Renewable Energy Laboratory, Golden Co (1994, 1995, 1997, 1999, 2001).

[21] J. Dussaud, personal communication.

[22] A. Houas, H. Lachheb, M. Ksibi, E. Elaloui, C. Guillard, and J. M. Herrmann, Appl. Catal. B: Environmental 31 (2001), 145.

[23] M. Vauthier, C. Guillard, and J. M. Herrmann, J. Catal. 201 (2001), 46.

[24] G. C. K. Low, S. R. Mc Evoy, and R. W. Matthews, Environ. Sci. Technol. 25 (1991), 460.

[25] E. Pelizzetti, C. Minero, P. Piccinini, and M. Vicenti, Coord. Chem. Rev. 125 (1993), 183.

[26] R. L. Burwell Jr, Adv. Catal. 26 (1977), 351.

[27] B. Krautler and A. J. Bard, J. Am. Chem. Soc. 100 (1978), 2239.

[28] A. Assabane, H. Tahiri, C. Guillard, Y. Ait-Ichou, and J. M. Herrmann, Appl. Catal. B: Environmental 24 (2000), 71.

[29] H. Tahiri, Y. Ait-Ichou, and J. M. Herrmann, J. Photochem. Photobiol. A: General 114 (1998), 219.

[30] H. Hidaka, K. Nohara, J. Zhao, E. Pelizzetti, and N. Serpone, J. Photochem. Photobiol. A: Chem. 91 (1995), 145. 


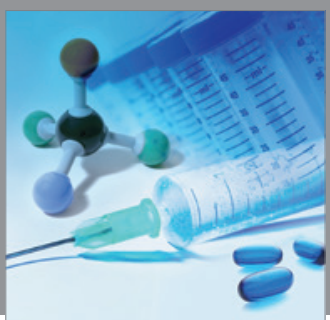

International Journal of

Medicinal Chemistry

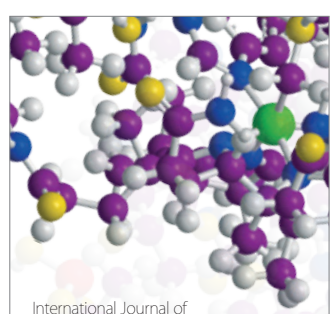

Carbohydrate Chemistry

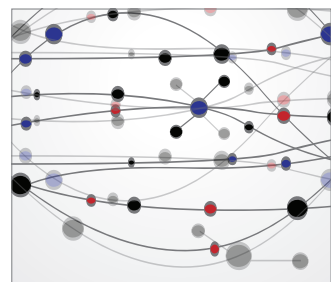

The Scientific World Journal
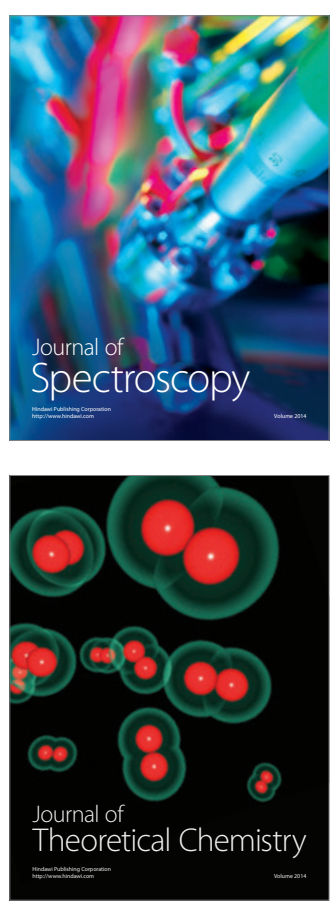
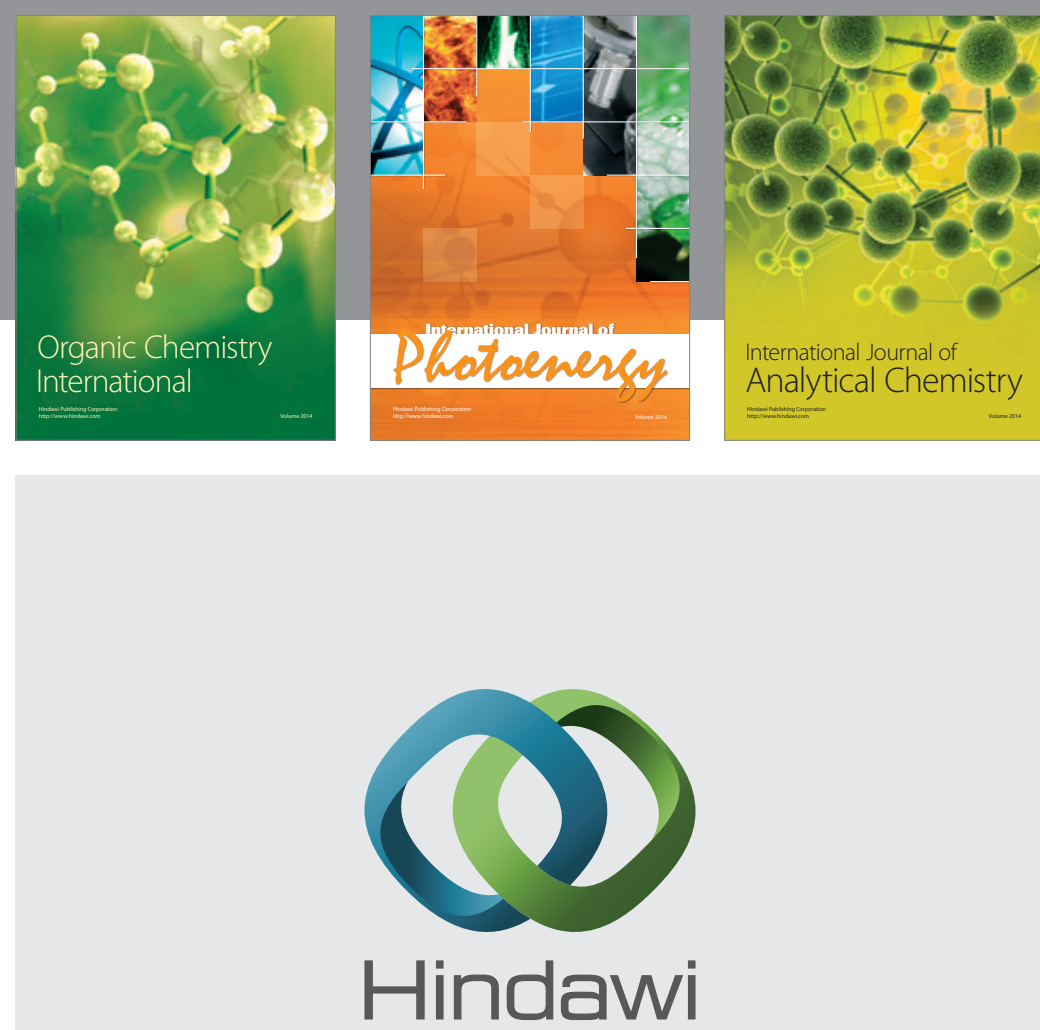

Submit your manuscripts at

http://www.hindawi.com
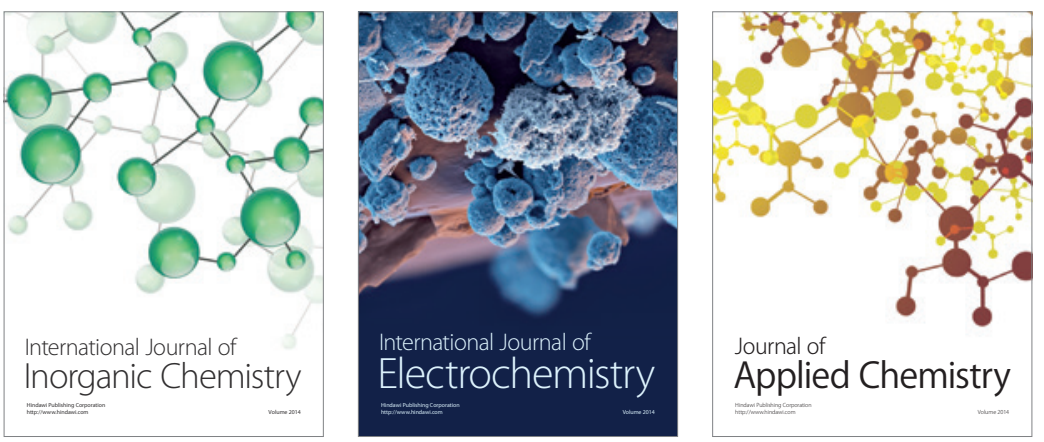

Journal of

Applied Chemistry
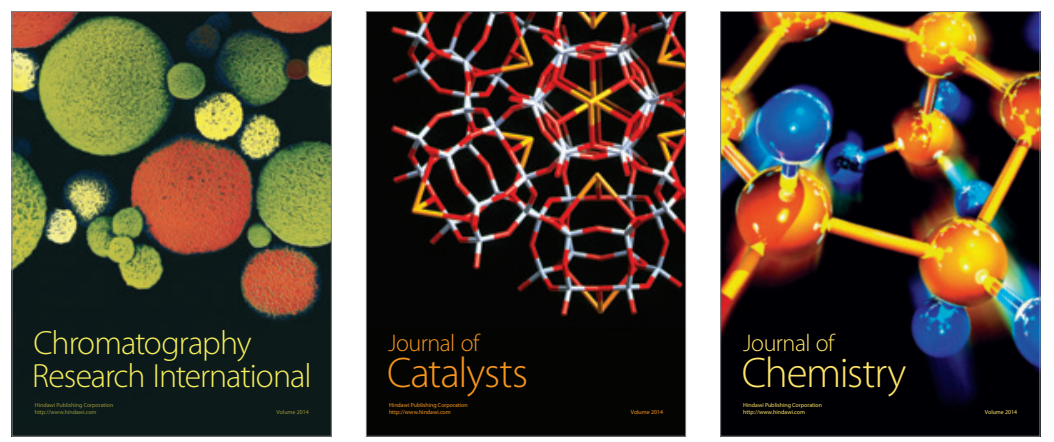
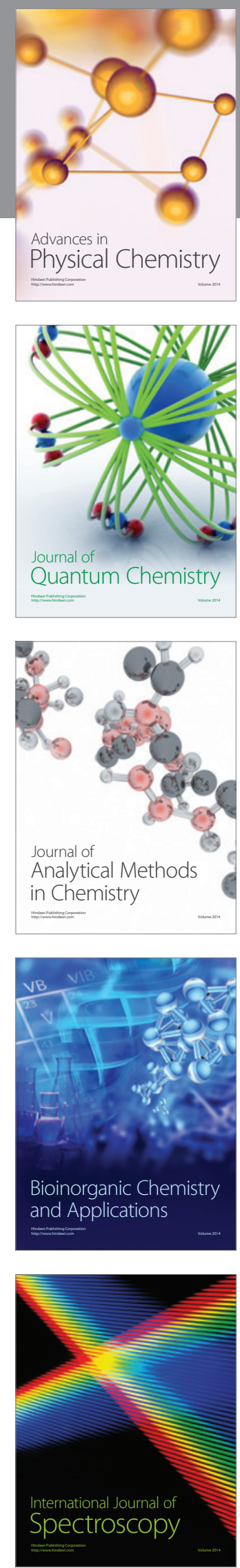